\title{
Karakteristik Soal Tes Masuk SMP Negeri di Kabupaten Bantul
}

\author{
Oleb:
}

Kabul Mulyana

\begin{abstract}
Abstrak
Penelitian ini bertujuan untuk mengetahui: karakteristik, kualitas, dan daya prediksi tes seleksi masuk SMP Negeri Kabupaten Bantul tahun pelajaran 2004/2005.

Subjek penelitian ini adalah butir soal tes seleksi masuk SMPN di Kabupaten Bantul, Daerah Istimewa Yogyakarta. Sumber data adalah 1.657 lembar jawaban (respon) peserta tes seleksi atas 100 butir soal pilihan ganda dengan 4 pilihan jawaban. Data dianalisis secara kuantitatif dengan teori tes klasik berbantuan komputer program MicroCat Iteman versi 3.00 dan dengan teori respons butir menggunakan bantuan komputer program MicroCat Bigsteps versi 2.30. Daya prediksi butir soal dianalisis secara regresi menggunakan program SPSS versi 11.00 .

Hasil analisis menggunakan teori tes klasik menunjukkan bahwa lima mata pelajaran (Kewarganegaraan, Bahasa Indonesia, Matematika, IPA, dan IPS) mempunyai indeks reliabilitas $>0,70$ dan hanya mata pelajaran matematika yang mempunyai tingkat kesukaran baik. Berdasarkan teori tes modern untuk kelima mata pelajaran, tingkat kesukaran, daya beda, fungsi informasi, dan kecocokan dengan model semuanya baik. Berdasarkan analisis butir soal menggunakan teori tes klasik 45\% jumlah butir soal baik, sedangkan berdasarkan analisis menggunakan teori respon $90 \%$ butir baik. Butir soal mata pelajaran matematika memiliki daya prediktif tertinggi $(\beta=0,282)$.
\end{abstract}

Kata kunci: karakteristik, tingkat kesukaran, dayja prediksi. 
Karakteristik Soal Tes Masuk SMP Negeri di Kabupaten Bantul

\section{Pendahuluan}

Saat ini pemerintah sedang giat melaksanakan otonomi daerah, maka tidak ketinggalan pemerintah Kabupaten Bantul lewat Dinas Pendidikan dan Kebudayaan juga berkepentingan untuk menyelenggarakan otonomi dalam bidang pendidikan. Untuk itu pemerintah Kabupaten Bantul telah menyusun suatu rencana strategis dalam dunia pendidikan, yang diharapkan dapat menjamin terlaksanannya pendidikan yang dapat meningkatkan kualitas sumber daya manusia, serta pemerataan kesempatan warga untuk mendapatkan pendidikan yang seluas-luasnya dan bermutu.

Mulai tahun pelajaran 2002/2003 program penerimaan siswa baru Sekolah Menengah Pertama (SMP) menggunakan sistem seleksi, dengan tes sesuai dengan surat Keputusan Menteri Pendidikan Nasional Nomor:51/U/2002, dengan pertimbangan bahwa (1) penerimaan siswa baru dengan cara yang lebih baik dapat meningkatkan mutu pendidikan dan mencapai sumber daya manusia yang berkualitas sesuai dengan kompetensi yang ditetapkan secara nasional, (2) dalam rangka pemberdayaan sekolah dengan prinsip manajemen berbasis sekolah, perlu lebih banyak memberikan kewenangan pada sekolah dalam penyelenggaraan penerimaan siswa baru.

Mengingat hal tersebut di atas, berdasarkan Musyawarah Kerja Kepala Sekolah SMP Negeri di Kabupaten Bantul, dalam program penerimaan siswa baru diadakan tes seleksi secara bersama-sama. Artinya waktu dan materi tes seleksi dilaksanakan bersamaan, tanpa mengurangi kewenangan dari setiap sekolah. Tes seleksi masuk SMP dillaksanakan dalam rangka memberdayakan sekolah sesuai dengan prinsip manajemen berbasis sekolah (MBS). Walaupun sekolah mempunyai kewenangan yang seluas-luasnya di dalam menentukan kriteria siswa yang dapat diterima, proses penerimaan ini harus tetap berasaskan objektivitas, transparansi, akuntabilitas, dan tidak diskriminatif. (1) Objektivitas, artinya penerimaan siswa baru harus memenuhi ketentuan yang berlaku. Untuk menjamin dan mendukung objektifitas tersebut, maka dalam pelaksanaan tes seleksi masuk SMP Negeri Kabupaten Bantul mempunyai karakteristik tersendiri. Adapun karakteristik itu antara lain (a) naskah soal disusun oleh Tim 
MKKS SMP Kabupaten Bantul yang dianggap mempunyai kemampuan untuk menyusun soal tes seleksi, (b) pendistribusian naskah soal disampaikan ke sekolah pada hari itu oleh Tim, (c) jumlah naskah soal disesuaikan dengan jumlah pendaftar, (d) lembar jawab komputer diserahkan ke panitia Kabupaten maksimal dua jam setelah pelaksanaan tes berlangsung, (e) koreksi lembar jawab langsung pada hari itu juga oleh tim koreksi tersendiri (oleh pihak ketiga) yang sudah ditunjuk dan yang diperbolehkan masuk ruang koreksi hanya petugas koreksi, Ketua dan sekretais MKKS SMP Kabupaten Bantul. (2) Transparansi, artinya pelaksanaannya harus bersifat terbuka dan dapat diketahui oleh masyarakat termasuk orang tua siswa, untuk menghindari penyimpanganpenyimpangan yang mungkin terjadi. Dalam menjamin transparasi pelaksanaan tes seleksi masuk SMP Kabupaten Bantul, maka hasil yang dicapai peserta tes disampaikan dan ditempel secara terbuka. Pelaksanaan pengumuman semua peserta yang diterima maupun yang tidak diterima, lengkap dengan nilai yang diperoleh dari masing-masing mata pelajaran, kemudian dijumlahkan dan diurutkan dari jumlah yang terbesar sampai yang terkecil. (3) Akuntabilitas, artinya dalam penerimaan siswa baru dapat dipertanggungjawabkan kepada masyarakat baik prosedur maupun hasilnya. Di dalam pelaksanaan tes masuk SMP Kabupaten Bantul agar akuntabilitasnya tinggi, maka menggunakan prosedur yang sangat ketat agar tidak terjadi kebocoran soal dan lembar jawab dikoreksi dengan komputer oleh pihak ketiga yang telah teruji kredibilitasnya. (4) Tidak diskriminatif, artinya setiap warga negara yang berusia sekolah dapat mengikuti program pendidikan tanpa membedakan suku, daerah asal, agama dan golongan.

Tes seleksi masuk sangat menentukan nasib peserta tes yaitu diterima atau tidaknya pada suatu sekolah. Sehubungan dengan hal itu, maka instrumen seleksi yang berupa soal-soal seleksi harus berkualitas, harus dapat memiliki daya beda yang tinggi untuk membedakan siswa yang berpotensi dan yang kurang berpotensi. Selain itu tes seleksi juga harus memiliki daya prediksi, sehingga dapat memprediksikan kemampuan dan keberhasilan siswa dimasa yang akan datang. Kualitas tes ini berkaitan dengan kemampuan apakah tes tersebut dapat mengestimasi seluruh 
potensi yang dimiliki siswa, sehingga dapat memilih peserta yang berkualitas. Dengan dipilihnya peserta yang berkualitas diharapkan dapat dicapai kualitas pendidikan SMP Negeri di Kabupaten Bantul yang baik karena kualitas siswa adalah unsur utama yang menentukan keberhasilan siswa dalam belajar.

Program pelaksanaan seleksi harus tetap berasaskan objektivitas, transparansi, akuntabilitas dan tidak diskriminatif, maka diperlukan suatu perangkat tes seleksi yang adil, yang tidak memihak pada suatu kelompok siswa tertentu. Jika pada suatu tes memuat suatu butir soal yang memihak pada kelompok tertentu, maka tes tersebut dikatakan memuat bias atau memuat keberfungsian butir diferensial (differential item fungtioning). Adanya butir diferensial ini mengakibatkan perangkat tes tersebut bersifat diskriminatif, atau memihak pada kelompok tertentu dan itu yang tidak diinginkan.

Pendidikan di SMP merupakan pendidikan dasar 9 tahun setelah Sekolah Dasar, maka dalam pelaksanaan tes seleksi masuk SMP tersebut juga harus mengacu pada program pendidikan dasar 9 tahun, artinya setiap siswa dari sekolah dasar di suatu wilayah harus dapat ditampung di SMP tanpa kecuali. Untuk itu di Kabupaten Bantul walaupun untuk masuk SMP diadakan seleksi tetap harus mempertimbangkan pendidikan dasar 9 tahun tersebut agar setiap lulusan sekolah dasar dapat diterima di sekolah menengah pertama. Dalam hal ini Pemerintah Kabupaten Bantul juga berkepentingan untuk menjamin terlaksananya pendidikan dalam rangka meningkatkan kualitas sumber daya manusia dan pemerataan kesempatan setiap warga usia sekolah untuk mendapatkan pendidikan yang memadai.

Pada program penerimaan siswa baru SMP, ada ketentuan yang harus dipatuhi oleh semua sekolah, bahwa sekolah dapat mengadakan seleksi calon siswa baru jika jumlah pendaftar melebihi daya tampung sekolah yang bersangkutan, sehingga apabila suatu sekolah jumlah pendaftar kurang dari daya tampung tidak diperkenankan mengadakan tes seleksi (semua pendaftar harus diterima). Mata pelajaran yang digunakan tes seleksi calon siswa baru kelas I SMP meliputi PPKn, Bahasa Indonesia, Matematika, IPA, dan IPS. Sedangkan penetapan penerimaan siswa baru kelas I SMP 
dengan mendasarkan pada jumlah nilai komulatif hasil tes dan nilai prestasi non akademik.

Seleksi dapat dipahami sebagai suatu kegiatan untuk memilih pendaftar pada suatu program yang telah direncanakan untuk mendapatkan peserta yang terbaik, dengan mempergunakan perangkat tes seleksi yang baik dan memenuhi kriteria yang telah ditetapkan. Dengan mengetahui kriteria siswa yang diterima, maka sekolah dapat memprediksikan keberhasilan siswa yang diterima, untuk itu perlu dihindari kesalahan prediksi akibat kesalahan pengukuran. Menurut Allen \& Yen (1979: 101) pengambilan keputusan dianggap tepat jika pada seleksi, pendaftar yang diterima akan berhasil dalam melaksanakan kegiatan dan pendaftar yang ditolak akan gagal dalam melaksanakan kegiatan yang dilakukan. Artinya pada seleksi tes masuk SMP, siswa yang diterima akan berhasil dalam mengikuti kegiatan pembelajaran dan calon siswa yang tidak diterima akan gagal dalam mengikuti kegiatan pembelajaran di suatu SMP.

Allen \& Yen(1979: 102) dan Sumadi Suryabrata (2005: 28), menggambarkan putusan seleksi sebagai berikut:

\begin{tabular}{|c|c|c|}
\hline Hasil & Berhasil & Gagal \\
\hline Berhasil & Benar & Salah \\
\hline Gagal & Salah & Benar \\
\hline
\end{tabular}

Sehubungan dengan hal itu, agar dapat memilih pendaftar yang baik, yaitu pendaftar yang diprediksikan berhasil dan ternyata memang berhasil dalam mengikuti kegiatan, maka diperlukan suatu perangkat tes seleksi yang baik. Menurut Djemari Mardapi (1997: 3), tes merupakan alat yang digunakan untuk pengukuran, yaitu mengumpulkan informasi karakteristik suatu objek. Respon siswa terhadap sejumlah pertanyaan menggambarkan kemampuan dalam bidang tertentu. Ketepatan suatu tes dapat diketahui dengan melihat tingkat reliabilitas dan validitasnya. Reliabilitas adalah konsistensi suatu instrumen pengukuran terhadap apapun yang diukur atau dinilai, besarnya nilai koefisien reliabilitas mengambil angka dari 0 sampai dengan 1,00 (Wiersma, 1986: 288). Reliabilitas dapat juga dikatakan sebagai derajat keajegan (consistency) di antara dua buah hasil pengukuran pada objek 
yang sama. Ebel (1986: 71) menyatakan bahwa koefisien reliabilitas untuk satu set nilai dari sekelompok subyek yang dinilai adalah koefisien korelasi antara satu set nilai dan satu set nilai yang lainnya pada test yang ekuivalen yang diperoleh secara terpisah pada kelompok subjek yang sama. Misalnya pengukuran validitas suatu perangkat tes dapat diartikan sebagai kemampuan suatu perangkat tes untuk mengukur apa yang seharusnya diukur (Allen \& Yenn, 1979: 95). Becker (1999) menyatakan: validity refers to the issue of whether the test measures what it is intending to measures, artinya validitas berhubungan dengan apakah test mengukur pokok masalah yang seharusnya diukur.

Pada waktu mengambil keputusan dalam seleksi, ada beberapa syarat yang harus dipenuhi, menurut Sumadi Suryabrata (2005: 26) syarat itu antara lain kecermatan prediksi (prediction effectiveness), efisiensi ekonomi (economics efficiency), dampak positif terhadap proses belajar mengajar (teacbing learning incentive) dan keadilan (equity). Selama ini keadilan yang dipraktekkan adalah memberikan kesempatan yang sama untuk mendaftar, sehingga peluang untuk diterima ditentukan oleh sistem seleksi dan alat seleksi yang digunakan (Saifudin Azwar, 1997: 3).

Berkaitan dengan hal tersebut di atas, selanjutnya diteliti: 1) Bagaimanakah karakteristik soal tes yang digunakan dalam program seleksi masuk SMP Negeri di Kabupaten Bantul tahun pelajaran 2004/2005 ditinjau dengan menggunakan teori tes klasik, 2) Bagaimanakah karakteristik soal tes yang digunakan dalam program seleksi masuk SMP Negeri di Kabupaten Bantul tahun pelajaran 2004/2005 ditinjau dengan menggunakan teori tes moderen, 3) Berapa besar daya prediksi perangkat tes yang digunakan dalam program tes seleksi masuk SMP Negeri di Kabupaten Bantul tahun pelajaran 2004/2005.

\section{Metode Penelitian}

Penelitian ini dirancang sebagai penelitian deskriptif kuantitatif ekplanatories dengan data berupa perangkat soal dan lembar jawab tes seleksi masuk SMP Kabupaten Bantul tahun pelajaran 2004/2005. Data yang ada dianalisis dengan menggunakan teori tes klasik dan teori respons 
butir, kemudian peneliti mendeskripsikan variabel yang diteliti dan menganalisisnya secara kuantitatif hubungan sebab akibat antarvariabel. Hubungan sebab akibat yang dimaksud dalam penelitian ini adalah pengaruh beberapa variabel prediktor terhadap prestasi belajar siswa di kelas VII SMP. Lokasi penelitian pada 9 SMP di Kabupaten Bantul yang mempresentasikan sebagai SMP dengan kategori kelompok atas, kelompok tengah, dan kelompok bawah berdasarkan peringkat rata-rata nilai ujian nasional tahun 2003/2004.

Subjek penelitian ini adalah butir soal tes masuk SMP Kabupaten Bantul tahun pelajaran 2004/2005 dan nilai asli ulangan blok semester ganjil tahun pelajaran 2004/2005 Kelas VII yang diambil secara random proporsional teridiri dari 9 (sembilan) dari 48 (empat puluh delapan) SMP negeri yang ada, tiga sekolah kelompok atas (SMP 2 Bantul, SMP 1 Sanden, dan SMP 1 Pundong), tiga sekolah kelompok tengah (SMP 1 Dlingo, SMP 2 Srandakan, dan SMP 2 Pandak), tiga sekolah kelompok bawah (SMP 2 Pundong, SMP 2 Sedayu, dan SMP 3 Pajangan).

Pengumpulan data penelitian ini dua macam. Pertama untuk pelaksanaan analisa butir soal untuk mengetahui karakteristik soal tes masuk adalah keseluruhan jawaban peserta tes masuk SMP Kabupaten Bantul tahun pelajaran 2004/2005 dari 9 sekolah didapat peserta sebanyak 1657 lembar jawaban. Kedua untuk pelaksanaan analisis kemampuan daya prediksi tes masuk terhadap keberhasilan dalam belajar sebanyak 1485 siswa seperti tersaji dalam tabel sebagai berikut.

Tabel 1

Jumlah Peserta Tes yang Diterima pada 9 Sekolah

\begin{tabular}{|c|l|c|c|}
\hline No & \multicolumn{1}{|c|}{ Nama Sekolah } & Jumlah Peserta Tes & Jumlah Diterima \\
\hline 1 & SMP N 1 Sanden & 206 & 160 \\
\hline 2 & SMP N 2 Bantul & 221 & 160 \\
\hline 3 & SMP N 1 Pundong & 242 & 240 \\
\hline 4 & SMP N 2 Srandakan & 176 & 120 \\
\hline 5 & SMP N 1 Dlingo & 224 & 200 \\
\hline 6 & SMP N 2 Pandak & 216 & 200 \\
\hline
\end{tabular}




\begin{tabular}{|c|c|c|c|}
\hline No & Nama Sekolah & Jumlah Peserta Tes & Jumlah Diterima \\
\hline 7 & SMP N 2 Sedayu & 116 & 116 \\
\hline 8 & SMP N 2 Pundong & 188 & 187 \\
\hline 9 & SMP N 3 Pajangan & 82 & 82 \\
\hline & $\mathrm{Jumlah}$ & 1657 & 1485 \\
\hline
\end{tabular}

Ada dua pendekatan yang digunakan untuk menganalisis karakteristik butir soal. Pertama, dengan menggunakan pendekatan teori tes klasik, untuk menentukan kualitas butir soal tes, yang meliputi tingkat kesukaran, daya beda, distribusi respon, indeks reabilitas, dan kesalahan baku pengukuran. Kualitas tes ini dapat diketahui dengan bantuan program Microcat Iteman versi 3,00. Kedua, dengan menggunakan pendekatan teori respon butir, kualitas butir tes dengan pendekatan ini dapat untuk menaksir kemampuan peserta tes, dengan bantuan program Microcat Bigsteps versi 2.30 .

Untuk menguji validitas prediktif tes yaitu analisis validitas prediksi antara skor tes seleksi masuk (sebagai variabel bebas) dengan (nilai ulangan blok semester I tahun pelajaran 2004/2005 (sebagai variabel terikat) menggunakan analisis statistik inferensial yaitu regresi ganda. Kepentingan analisis dengan menggunakan regresi dalam penelitian ini sebatas untuk mengetahui seberapa dukungan dari masing-masing prediktor, terhadap hasil belajar, dengan menggunakan komputer program SPSS versi 11.00 for Windows.

\section{Hasil Penelitian dan Pembahasan}

Berdasarkan hasil penelitian dan pembahasan pada perangkat tes seleksi masuk SMP Negeri di Kabupaten Bantul, dapat diperoleh hasil sebagai berikut:

1. Banyaknya butir soal tes seleksi masuk SMP Kabupaten Bantul ada 100 nomor yang terdiri dari 5 mata pelajaran PPKn, Bahasa Indonesia, Matematika, IPA, dan IPS masing-masing 20 nomor.

2. Analisis butir dengan program iteman yang dilakukan terhadap respon siswa adalah untuk mencari besarnya tingkat kesukaran, daya beda, 
efektifitas pengecoh, dan indeks reabilitas dari masing-masing mata pelajaran dan hasilnya seperti pada tabel sebagai berikut:

Tabel 2

Rangkuman Hasil Analisis dengan Program Iteman 5 Mata Pelajaran, Masing-masing 20 Butir Soal

\begin{tabular}{|c|c|c|c|c|c|c|c|c|c|}
\hline \multirow{2}{*}{ No } & \multirow{2}{*}{$\begin{array}{c}\text { Mata } \\
\text { Pelajaran }\end{array}$} & \multicolumn{3}{|c|}{$\begin{array}{l}\text { Proporsi Tingkat } \\
\text { Kesukaran }\end{array}$} & \multicolumn{2}{|c|}{$\begin{array}{l}\text { Proporsi Daya } \\
\text { Beda }\end{array}$} & \multicolumn{2}{|c|}{$\begin{array}{l}\text { Proporsi Distribusi } \\
\text { Jawaban }\end{array}$} & \multirow{2}{*}{$\begin{array}{l}\text { Relia } \\
\text { bilitas }\end{array}$} \\
\hline & & $\begin{array}{l}\text { Mu- } \\
\text { dah }\end{array}$ & $\begin{array}{c}\text { Se- } \\
\text { dang }\end{array}$ & $\begin{array}{l}\text { Su- } \\
\text { kar }\end{array}$ & Baik & $\begin{array}{c}\text { Tidak } \\
\text { Baik }\end{array}$ & $\begin{array}{l}\text { Ber- } \\
\text { fungsi }\end{array}$ & $\begin{array}{c}\text { Tidak } \\
\text { Berfungsi }\end{array}$ & \\
\hline 1 & PPKn & 16 & 3 & 1 & 14 & 6 & 18 & 2 & 0,902 \\
\hline 2 & $\begin{array}{c}\text { Bahasa } \\
\text { Indone- } \\
\text { sia }\end{array}$ & $\overline{14}$ & 6 & 0 & 14 & 6 & 19 & 1 & 0,854 \\
\hline 3 & $\begin{array}{l}\text { Matema- } \\
\text { tika }\end{array}$ & 2 & 17 & 1 & 13 & 7 & 13 & 7 & 0,901 \\
\hline 4 & IPA & 7 & 9 & 4 & 16 & 4 & 14 & 6 & 0,887 \\
\hline 5 & $\overline{\text { IPS }}$ & 10 & 10 & 0 & 17 & 3 & 17 & 3 & 0,825 \\
\hline \multicolumn{2}{|c|}{ Jumlah Total } & $49 / 100$ & $45 / 100$ & $6 / 100$ & $74 / 100$ & $26 / 100$ & $81 / 100$ & $19 / 100$ & 0,868 \\
\hline
\end{tabular}

Hasil penelitian menunjukkan bahwa:

a. Tingkat kesukaran butir soal, dari keseluruhan jumlah soal tes seleksi sebanyak 100 soal temyata ada 49 soal dengan kategori mudah, 45 soal dengan kategori sedang, dan 6 soal dengan kategori sukar.

b. Daya pembeda soal kelima mata pelajaran ternyata mempunyai indeks daya beda yang baik, dan jika dilihat secara kesluruhan jumlah soal tes seleksi mempunyai daya beda baik sebanyak $74 \%$, jadi dapat dikatakan bahwa soal tes seleksi masuk SMP Kabupaten Bantul tahun pelajaran 2004/2005 mempunyai kemampuan untuk membedakan siswa yang pandai dan yang kurang pandai.

c. Ditinjau dari distribusi respon (jawaban) untuk keseluruhan jumlah soal tes seleksi masuk SMP Kabupaten Bantul tahun pelajaran 2004/2005 didapat $81 \%$ distribusi respon berfungsi baik dan $19 \%$ berfungsi tidak 
baik dan rata-rata jumlah soal yang dijawab benar adalah 64,62 atau sudah lebih besar dari 50\% soal dapat dikerjakan. Jadi dapat dikatakan bahwa soal tes seleksi masuk SMP Kabupaten Bantul tahun pelajaran 2004/2005 mempunyai distribusi jawaban yang baik.

d. Dilihat dari indeks reabilitas menunjukkan bahwa semua mata pelajaran dinyatakan mempunyai indeks reliabilitas yang baik di atas 0,70 dan untuk keseluruhan butir soal tes seleksi masuk SMP Kabupaten Bantul mempunyai indeks reliabilitas yang baik yaitu 0,868.

3. Analisis butir dengan program Bigsteps versi 2.30 yang dilakukan terhadap respon siswa adalah untuk mengetahui tingkat kesukatan, daya beda, fungsi informasi, dan tingkat kecocokan butir soal dengan bantuan program Bigsteps dari 5 mata pelajaran masing-masing sebanyak 20 butit, dapat disajikan sebagai berikut:

Tabel 3

Rekapitulasi Hasil Analisis dengan Program Bigsteps

5 Mata Pelajaran Masing-masing 20 Butir Soal

\begin{tabular}{|c|c|c|c|c|c|c|c|c|c|c|}
\hline \multirow{2}{*}{ No } & \multirow{2}{*}{$\begin{array}{l}\text { Mata- } \\
\text { Pela- } \\
\text { jaran }\end{array}$} & \multicolumn{3}{|c|}{ Tingkat Kesukaran } & \multicolumn{2}{|c|}{ Daya Beda } & \multicolumn{2}{|c|}{$\begin{array}{c}\text { Proporsi Fungsi } \\
\text { Informasi }\end{array}$} & \multicolumn{2}{|c|}{$\begin{array}{c}\text { Proporsi } \\
\text { Kecocokan }\end{array}$} \\
\hline & & $\begin{array}{l}\text { Mu- } \\
\text { dah }\end{array}$ & $\begin{array}{c}\text { Se- } \\
\text { dang }\end{array}$ & $\begin{array}{l}\text { Su- } \\
\text { kar }\end{array}$ & Baik & $\begin{array}{l}\text { Tidak } \\
\text { Baik }\end{array}$ & Baik & $\begin{array}{l}\text { Tidak } \\
\text { Baik }\end{array}$ & $\begin{array}{l}\text { Co- } \\
\text { cok }\end{array}$ & $\begin{array}{l}\text { Tidak } \\
\text { Cocok }\end{array}$ \\
\hline 1 & PPKn & 3 & 13 & 4 & 19 & & 14 & 6 & 17 & 3 \\
\hline 2 & $\begin{array}{l}\text { Bahasa } \\
\text { Indone- } \\
\text { sia }\end{array}$ & - & 20 & - & 20 & - & 19 & 1 & 14 & 6 \\
\hline 3 & $\begin{array}{l}\text { Matema- } \\
\text { tika }\end{array}$ & 1 & 19 & - & 19 & 1 & 14 & 6 & 12 & 8 \\
\hline 4 & IPA & - & 19 & 1 & 20 & - & 18 & 2 & 14 & 6 \\
\hline 5 & IPS & & 19 & 1 & 20 & - & 16 & 4 & 16 & 4 \\
\hline Juml & h Total & 4 & 90 & 6 & 98 & 2 & 81 & 19 & 73 & 17 \\
\hline
\end{tabular}

Hasil penelitian menunjukkan bahwa:

a. Persentase kecocokan dengan model Rasch secara keseluruhan mencapai $73 \%$. 
b. Tingkat kesukaran butirnya ternyata bahwa setiap mata pelajaran mempunyai tingkat kesukaran sedang (baik) lebih dari 50\%.

c. Hasil analisis tentang daya pembeda pada model Rasch menunjukkan bahwa kelima mata pelajaran mempunyai $\mathrm{pt}_{\text {bis }}$ negatif jumlah persentasenya sangat kecil (sangat baik).

d. Hasil analisis tahap akhir menunjukkan bahwa fungsi informasi butir soal yang memiliki nilai maksimum $>0,70$ jumlahnya lebih besar dari $70 \%$, sehingga dapat dikatakan bahwa butir soal tersebut cermat dalam melakukan fungsi ukurnya.

4. Untuk mengetahui daya prediksi perangkat tes seleksi masuk SMP Kabupaten Bantul tahun pelajaran 2004/2005 dan kontribusi dari masing-masing mata pelajaran terhadap prestasi hasil belajar maka diadakan analisis regresi dengan bantuan program SPSS versi 11.00 for Windows. Hasil analisis dapat dirangkum sebagai berikut:

Tabel 4

Nilai Prediksi Mata Pelajaran dari Masing-masing Sekolah

\begin{tabular}{|c|l|c|c|c|c|c|c|c|c|c|c|}
\hline No & \multirow{2}{*}{$\begin{array}{c}\text { Mata Pela- } \\
\text { jaran }\end{array}$} & \multicolumn{6}{|c|}{ Nilai Prediksi Mata Pelajaran dari Masing-masing Sekolah } \\
\cline { 3 - 12 } & 1 & 2 & 3 & 4 & 5 & 6 & 7 & 8 & 9 & Mean \\
\hline 1 & PPKn & 0.176 & 0.143 & 0.178 & 0.058 & 0.175 & 0.206 & 0.117 & 0.231 & 0.136 & 0.158 \\
\hline 2 & $\begin{array}{l}\text { Bahasa Indo- } \\
\text { nesia }\end{array}$ & 0.220 & 0.175 & 0.244 & 0.189 & 0.209 & 0.229 & 0.080 & 0.215 & 0.113 & 0.186 \\
\hline 3 & Matematika & 0.323 & 0.255 & 0.349 & 0.333 & 0.258 & 0.263 & 0.210 & 0.242 & 0.307 & 0.282 \\
\hline 4 & IPA & 0.383 & 0.151 & 0.134 & 0.305 & 0.277 & 0.290 & 0.139 & 0.215 & 0.185 & 0.231 \\
\hline 5 & IPS & 0.321 & 0.177 & 0.245 & 0.258 & 0.335 & 0.335 & 0.247 & 0.233 & 0.085 & 0.248 \\
\hline
\end{tabular}

Keterangan:

1. SMP 1 Sanden

2. SMP 2 Bantul

3. SMP 1 Pundong
4. SMP 2 Srandakan

5. SMP 1 Dlingo

6. SMP 2 Pandak
7. SMP 2 Sedayu

8. SMP 2 Pundong

9. SMP 3 Pajangan

Hasil analisis regresi menunjukkan bahwa:

a. Soal mata pelajaran PPKn mempunyai daya prediktif terendah di antara kelima prediktor, sehingga keberadaan sebagai alat tes seleksi perlu dikaji lebih dalam. 
b. Soal mata pelajaran Bahasa Indonesia mempunyai daya prediktif tinggi di sekolah pada kelompok atas saja.

c. Soal mata pelajaran Matematika mempunyai daya prediktif tertinggi di antara kelima prediktor.

d. Soal mata pelajaran IPA mempunyai daya prediktif tinggi di sekolah pada kelompok menengah.

e. Soal mata pelajaran IPS mempunyai daya prediktif ada yang tinggi maupun yang rendah merata disemua sekolah pada kelompok atas, menengah maupun bawah, sehingga perlu dikembangkan butir soal yang memerlukan analisis bukan hanya bentuk hafalan saja.

\section{Kesimpulan}

Berdasarkan diskripsi hasil penelitian dan pembahasan, dapat disimpulkan sebagai berikut:

1. Hasil analisis butir soal tes seleksi masuk SMP Kabupaten Bantul tahun pelajaran 2004/2005 dengan menggunakan program Iteman, menunjukkan bahwa dari lima mata pelajaran hanya ada satu mata pelajaran tergolong mempunyai indeks kesukaran yang baik atau sedang, yaitu matematika sedang yang lain kurang baik. Ditinjau dari daya beda, semuanya tergolong baik. Ditinjau dari distribusi jawaban siswa semuanya tergolong baik, dan dilihat dari tingkat reliabilitas juga semuanya tergolong baik.

2. Hasil analisis butir soal tes seleksi masuk SMP Kabupaten Bantul tahun pelajaran 2004/2005 dengan menggunakan program Bigsteps, menunjukkan bahwa semua mata pelajaran (PPKn, Bahasa Indonesia, Matematika, IPA, dan IPS) mempunyai tingkat kesukaran baik, daya beda baik, fungsi informasi baik, dan kecocokan dengan model baik.

3. Hasil analisis regresi menunjukkan bahwa soal mata pelajaran Matematika memiliki daya prediktif tertinggi di antara kelima prediktor, diikuti mata pelajaran IPA, mata pelajaran IPS, mata pelajaran Bahasa Indonesia dan yang terakhir mata pelajaran PPKn. 


\section{Saran-saran}

Berdasarkan hasil penelitian diperlukan adanya kajian ilmiah secara lebih mendalam dalam pelaksanaan tes seleksi terutama dalam pelaksanaan penyusunan butir soal, dan dapat dikemukakan saran sebagai berikut:

1. Perangkat soal tes seleksi masuk SMP Kabupaten Bantul tahun 2004/2005, jika dianalisis dengan menggunakan teori tes klasik masih ditemukan ada butir soal yang daya pengecohnya perlu diperbaiki. Untuk itu petlu adanya langkah pengembangan dan pelatihan para pembuat soal tes seleksi harus menguasai teknik dan keterampilan pembuatan soal yang baik terutama soal pilihan ganda.

2. Untuk menganalisis hasil tes seleksi masuk yang skala besar akan lebih tepat menggunakan teori respon butir.

3. Dalam tes seleksi masuk SMP Kabupaten Bantul, sangat memungkinkan ada siswa secara akademik sebenarnya sangat potensial tetapi tidak terjaring lolos dalam seleksi yang hanya mengandalkan tes seleksi saja dimana tesnya belum teruji validitas dan reliabilitasnya. Komunitas akademik telah mengetahui bahwa motivasi dari suatu tes, termasuk tes seleksi masuk SMP Negeri di Kabupaten Bantul memang bukan untuk seleksi, melainkan untuk mengukur seberapa hasil belajar dari pengalaman yang pernah diikuti. Sehingga tidak ada jaminan bahwa tes seleksi ini merupakan satu-satunya prediktor kemampuan siswa untuk mengikuti pembelajaran di SMP perlu penelitian lebih lanjut.

\section{Daftar Pustaka}

Allen, M., J. \& Yen, W., M.(1979). Introduction to measurement theory. Belmont, California; Wadswort, Inc.

Becker, L., A. (1999). Reliability and validity, Part I and II. Diambil dari: http://712education.about.com/library/glossary/terms/bldefvaliditv .htm/ validity/in testing/ pada tanggal 3 Februari 2007, pukul 11.25 wib. 
Djemari Mardapi. (1991). Konsep dasar teori respons butir: Perkembangan dalam Bidang Pengukuran Pendidikan. Cakrawala Pendidikan No.3 tahun X, 116. (1997). Ragam dan bentuk evaluasi. Bahan Semiloka Evaluasi Sistem Penilaian dan Pengukuran Prestasi Belajar Mahasiswa UGM.

Ebel, R., L. \& Frisbie, D., A. (1986). Essentials of educational measurement. New Jersey: Prencise Hail, Inc. Englewood Clieffs.

Saefuddin Aswar. (2007). Tes Prestasi: Fungsi pengembangan pengukuran prestasi belajar. Yogyakarta: Pustaka Pelajar.

Sumadi Suryabrata. (2005). Seleksi calon mabasiswa baru perguruan tinggi. Dalam pengantar Djemari Mardapi, Rekayasa Sistem Penilaian dalam Rangka Meningkatkan Kualitas Pendidikan (pp. 24-41). Yogyakarta: HEPI. .(1987). Pengembangan tes hasil belajar. Jakarta: Rajawali Pers.

Wiersma, W. (1986). Research methods in education: An introduction, Boston: Allyn and Bacon, Inc.

\section{Biodata Penulis}

Kabul Mulyana. Lahir di Kulon Progo, 14 Januari 1961. Pendidikan S2, Program Studi Penelitian dan Evaluasi Pendidikan, Program Pascasarjana Universitas Negeri Yogyakarta, tahun 2007. Penulis bekerja sebagai staf pengajar di SMU Negeri 1 Srandakan, Bantul. 